\title{
Treatment of hepatitis $C$ virus infection in the future
}

Tatsuo Kanda ${ }^{1 *}$, Osamu Yokosuka ${ }^{1}$ and Masao Omata ${ }^{2,3^{*}}$

\begin{abstract}
Two direct-acting antivirals (DAAs) against hepatitis $\mathrm{C}$ virus (HCV): telaprevir and boceprevir, are now available in combination with peginterferon plus ribavirin for the treatment of chronic hepatitis $C$ infection. Although these drugs are potent inhibitors of HCV replication, they occasionally result in severe adverse events. In the present clinical trials, in their stead, several second-generation DAAs are being investigated. Most of them are being viewed with high expectations, but they also require the combination with peginterferon plus ribavirin. In the near future, we might be using all-oral DAAs and interferon-free regimens for the treatment of HCV-infected patients, and these would be potent inhibitors of HCV and have less adverse events.
\end{abstract}

Keywords: HCV, Telaprevir, Boceprevir, Sofosbuvir, Daclatasvir

\section{Review}

\section{Introduction}

Hepatitis C virus (HCV) chronically infects an estimated 170 million people worldwide [1]. HCV infection is one of the major causes of end-stage liver disease and hepatocellular carcinoma (HCC) worldwide [2-4]. Approximately $30 \%$ of patients who develop acute hepatitis $\mathrm{C}$ recover spontaneously, signaled by improved symptoms, normalized liver-related chemistries, loss of HCV RNA from serum, and the development of $\mathrm{HCV}$ antibody [5-7]. In chronic hepatitis $\mathrm{C}$, the progression of liver fibrosis is slow, but steady. It has been reported that the progression rate of liver fibrosis is $0.10-0.13 \mathrm{U} /$ year in untreated patients [8]. Progression of chronic HCV infection is not linear in time, probably because many cofactors are involved in changing the rate of development of fibrosis, cirrhosis, and HCC [6]. Cirrhosis rates become significant after 20 years of $\mathrm{HCV}$ infection. About 20-30\% of patients could develop a progressive liver disease leading to cirrhosis and HCC [5,7]. HCC develops at about $1-7 \%$ per year [5,7]. It has been demonstrated that subjects who achieve sustained virological response

\footnotetext{
* Correspondence: kanda2t@yahoo.co.jp; momata-tky@umin.ac.jp

'Department of Gastroenterology and Nephrology, Chiba University, Graduate School of Medicine, 1-8-1 Inohana, Chuo-ku, Chiba (260-8670), Japan

${ }^{2}$ Yamanashi Hospitals (Central and Kita) Organization, 1-1-1 Fujimi, Kofu-shi, Yamanashi (400-8506), Japan

Full list of author information is available at the end of the article
}

(SVR) have a clear advantage at histological and clinical levels compared to those who do not achieve SVR [8-12]. The present standard for the judgment of SVR is undetectability of serum HCV RNA at 24 weeks posttreatment.

Preventive measures against $\mathrm{HCV}$, including vaccine development, are now in progress [13]. But the standard of care (SOC), peginterferon and ribavirin therapy, and new standard of care (NSOC), combination protease inhibitors such as telaprevir or boceprevir with peginterferon plus ribavirin therapy, have been approved for the eradication of HCV in US, Europe, and Japan [14-18]. Even with these advances in antiviral therapies against $\mathrm{HCV}$, SVR rates were $~ 70 \%$ in HCV genotype-1 treated with NSOC and $\sim 80 \%$ in HCV genotype-2/3 treated with SOC. Rash also occurs in $56 \%$ of patients treated with NSOC, compared to $34 \%$ of patients treated with SOC alone. Other adverse events were still present [19], although even interferon is also associated with severe adverse events [20]. When we treat patients infected with $\mathrm{HCV}$ in daily clinical practice, it seems important to be aware of the potential treatments of $\mathrm{HCV}$ in the near future, as the development of new drugs is always ongoing.

$\mathrm{HCV}$ belongs to the flaviviridae family, and HCV genome is a positive-strand $~ 9.6-\mathrm{kb}$ RNA. HCV has a $5^{\prime}$ untranslated region ( $\left.5^{\prime} \mathrm{UTR}\right)$, a long open reading frame, and a $3{ }^{\prime}$ UTR. An internal ribosomal entry site (IRES), containing the $5^{\prime} \mathrm{UTR}$ and part of the core coding

\section{实}




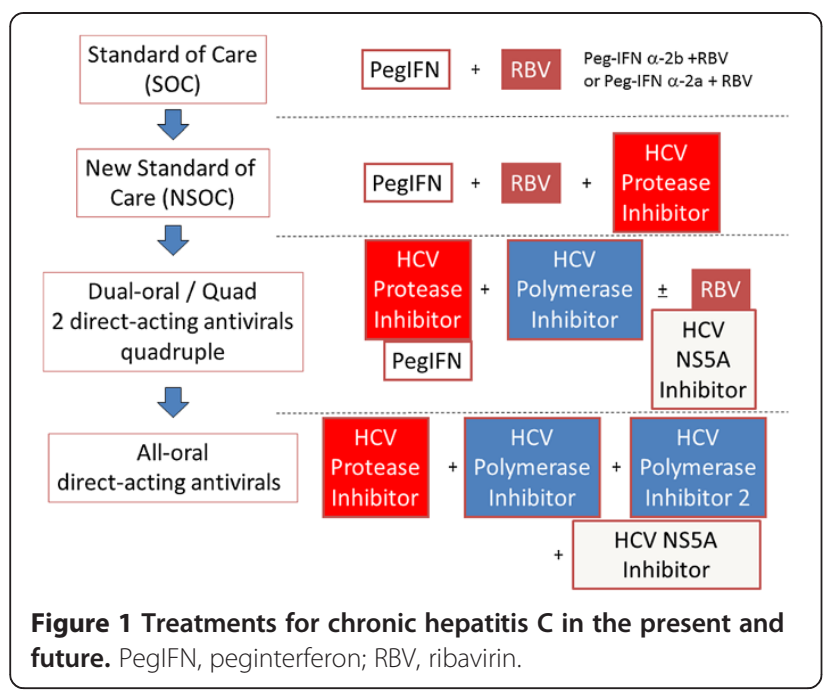

Figure 1 Treatments for chronic hepatitis $\mathrm{C}$ in the present and ure. PegIFN, peginterferon; RBV, ribavirin region, forms a stem-loop structure and supports translation initiation of $\mathrm{HCV}$ genome in a cap-independent manner $[21,22]$. HCV genome encodes a single precursor polyprotein that is processed by host signal peptidases and $\mathrm{HCV}$ proteases, resulting in structural (core, envelopes E1 and E2, and p7) and nonstructural (NS2, NS3, NS4A, NS4B, NS5A and NS5B) proteins. Directacting antivirals (DAAs) against $\mathrm{HCV}$ are classified into several categories: 1) HCV NS3/4A protease inhibitors, 2) HCV NS5B polymerase inhibitors, 3) HCV NS5A inhibitors, and others. In the near future, interferonsparing regimens and treatment with all-oral DAAs will play major roles in treating $\mathrm{HCV}$-infected patients (Figure 1).

\section{Standard of care (SOC) treatment for HCV infection}

Interferon, combination interferon plus ribavirin, and peginterferon plus ribavirin increased SVR rate from $\sim 5 \%$ to $\sim 40-80 \%$, depending on the HCV genotypes $[18,23]$. Peginterferon plus ribavirin treatment for 48 weeks, the SOC treatment for HCV genotype 1-infected patients,

Table 1 Standard of care treatment and sustained virological response rates for chronic hepatitis $C$ patients

\begin{tabular}{|c|c|c|c|c|c|c|c|}
\hline References & G & $\begin{array}{l}\text { Number of } \\
\text { patients }\end{array}$ & $\begin{array}{l}\text { Naïve or } \\
\text { re-treatment }\end{array}$ & Formula of therapy & $\begin{array}{l}\text { Duration of treatment } \\
\text { (weeks) }\end{array}$ & $\begin{array}{l}\text { SVR rates } \\
(\%)\end{array}$ & Notes \\
\hline \multirow[t]{3}{*}{ [24] } & G1 & 298 & & $\begin{array}{l}\text { Peginterferon alfa-2a plus } \\
\text { ribavirin }\end{array}$ & 48 & 46 & \\
\hline & & 285 & & $\begin{array}{l}\text { Interferon alfa-2b plus } \\
\text { ribavirin }\end{array}$ & 48 & 36 & \\
\hline & & $\overline{145}$ & & $\begin{array}{l}\text { Peginterferon alfa-2a plus } \\
\text { placebo }\end{array}$ & 48 & 21 & \\
\hline \multirow[t]{3}{*}{ [24] } & G2/G3 & 140 & & $\begin{array}{l}\text { Peginterferon alfa-2a plus } \\
\text { ribavirin }\end{array}$ & 48 & 76 & \\
\hline & & 145 & & $\begin{array}{l}\text { Interferon alfa-2b plus } \\
\text { ribavirin }\end{array}$ & 48 & 61 & \\
\hline & & 69 & & $\begin{array}{l}\text { Peginterferon alfa-2a plus } \\
\text { placebo }\end{array}$ & 48 & 45 & \\
\hline \multirow[t]{3}{*}{ [24] } & G4 & 13 & & $\begin{array}{l}\text { Peginterferon alfa-2a plus } \\
\text { ribavirin }\end{array}$ & 48 & 77 & \\
\hline & & 11 & & $\begin{array}{l}\text { Interferon alfa-2b plus } \\
\text { ribavirin }\end{array}$ & 48 & 36 & \\
\hline & & 9 & & $\begin{array}{l}\text { Peginterferon alfa-2a plus } \\
\text { placebo }\end{array}$ & 48 & 22 & \\
\hline \multirow[t]{2}{*}{ [25] } & $\begin{array}{l}\mathrm{G} 1 \\
(98 \%)\end{array}$ & 100 & & $\begin{array}{l}\text { Peginterferon alfa-2b plus } \\
\text { placebo }\end{array}$ & 48 & 19 & Blacks \\
\hline & & 100 & & $\begin{array}{l}\text { Peginterferon alfa-2a plus } \\
\text { ribavirin }\end{array}$ & 48 & 52 & $\begin{array}{l}\text { Non-Hispanic } \\
\text { Whites }\end{array}$ \\
\hline \multirow[t]{2}{*}{ [26] } & $\mathrm{G} 2 / 3$ & 732 & & $\begin{array}{l}\text { Peginterferon alfa-2a plus } \\
\text { ribavirin }\end{array}$ & 16 & 65 & \\
\hline & & 731 & & $\begin{array}{l}\text { Peginterferon alfa-2a plus } \\
\text { ribavirin }\end{array}$ & 24 & 76 & \\
\hline \multirow[t]{2}{*}{ [27] } & G1 & 269 & naive & $\begin{array}{l}\text { Peginterferon alfa-2a plus } \\
\text { ribavirin }\end{array}$ & 48 & 34 & Latino \\
\hline & & 300 & naive & $\begin{array}{l}\text { Peginterferon alfa-2a plus } \\
\text { ribavirin }\end{array}$ & 48 & 49 & Non-Latino \\
\hline
\end{tabular}


leads to only $\sim 50 \%$ SVR in those patients with high viral loads, who were mostly null-responders or relapsers [23-27]. On the other hand, peginterferon plus ribavirin treatment for 24 weeks, the SOC treatment for $\mathrm{HCV}$ genotype 2-infected patients, leads to $\sim 80 \%$ SVR in those patients (Table 1). Race has been shown to be a factor in the response to therapy for $\mathrm{HCV}$ infection [25,27]. A higher homocysteine level is also one of factors predicting a nonresponse to treatment [28]. Because the favorable interleukin 28B (IL28B) associated-single nucleotide polymorphisms (SNPs), leading to better response, exist at substantially greater frequency in European than African populations, they also explain approximately half of the difference in response rates between African-Americans and patients of European ancestry [29]. IL28B SNPs help to improve the treatment outcomes in HCV-patients treated with SOC [29-34]. In future interferon-included regimens, IL28B SNPs may also provide useful information about the treatment response even before treatment.

New standard of care (NSOC) treatment for HCV infection In 2011, telaprevir and boceprevir were the first approved DAAs against $\mathrm{HCV}$. The triple combination therapy of telaprevir or boceprevir plus ribavirin and peginterferon-alfa is the NSOC treatment for chronic HCV genotype 1-infected patients [35-42]. Telaprevir (VX-950) is a potent, selective inhibitor of NS3/4A protease, which is essential for $\mathrm{HCV}$ replication [43]. SVR rates among treatment-naïve patients were $\sim 70 \%$ in telaprevir-included regimens $[35,36,38,40]$. The SVR rates among patients with no previous response were $30 \sim 40 \%$ and those among patients with a previous relapse were $70 \sim 75 \%$, both in telaprevir-included regimens $[37,39]$. SVR rates were significantly higher in telaprevirincluded regimens than in SOC among patients who had a previous relapse $(83-88 \%$ vs. $24 \%)$, a partial response (54-59\% vs. $15 \%)$ and non- response $(29-33 \%$ vs. $5 \%)$ $[39,44]$. Thus, SVR rates were higher among patients who had previously had relapses than among nonresponders. Response-guided therapy is also useful in the telaprevir-included regimen (Table 2) [40]. Boceprevir ( $\mathrm{SCH} 503034)$ is a potent ketoamide inhibitor of $\mathrm{HCV}$ NS3 serine protease [45]. The addition of boceprevir to SOC results in higher SVR rates in both treatment-naïve and re-treated patients infected with HCV genotype 1 (Table 3) [41,42]. SVR rates were significantly higher in boceprevir-included regimens than in SOC among patients who had a prior relapse $(69-75 \%$ vs. $29 \%$ ) or a prior nonresponse (40-52\% vs. 7\%) [42]. Viewed from

Table 2 New standard of care treatment with telaprevir for chronic hepatitis $C$ patients

\begin{tabular}{|c|c|c|c|c|c|c|}
\hline References & G & $\begin{array}{l}\text { Number of } \\
\text { patients }\end{array}$ & $\begin{array}{l}\text { Naïve or } \\
\text { re-treatment }\end{array}$ & $\begin{array}{l}\text { Formula of therapy, and duration of treatment } \\
\text { (weeks) }\end{array}$ & $\begin{array}{l}\text { SVR rates } \\
(\%)\end{array}$ & Notes \\
\hline \multirow[t]{4}{*}[35]{} & G1 & 79 & naive & T12PR24 & 61 & PROVE1 Study \\
\hline & & 79 & naive & T12PR48 & 67 & \\
\hline & & 17 & naive & T12PR12 & 35 & \\
\hline & & 75 & naive & PR48 & 41 & \\
\hline \multirow[t]{4}{*}{ [36] } & G1 & 81 & naive & T12PR24 & 69 & PROVE2 Study \\
\hline & & 82 & naive & T12PR12 & 60 & \\
\hline & & 78 & naive & $\mathrm{T} 12 \mathrm{P} 12$ & 36 & \\
\hline & & 42 & naive & PR48 & 46 & \\
\hline \multirow[t]{4}{*}[37]{} & G1 & 115 & re-treatment & T12PR24 & 51 & PROVE3 Study \\
\hline & & 113 & re-treatment & T12PR48 & 53 & \\
\hline & & 111 & re-treatment & T24P24 & 24 & \\
\hline & & 114 & re-treatment & PR48 & 14 & \\
\hline \multirow[t]{3}{*}{ [38] } & G1 & 363 & naive & $\mathrm{T} 12 \mathrm{PR}$ & 73 & ADVANCE Study \\
\hline & & 364 & naive & T8PR & 67 & \\
\hline & & 49 & naïve & PR48 & 44 & \\
\hline \multirow[t]{3}{*}{ [39] } & G1 & 145 & re-treatment & T12PR48 & 93 & REALIZE Study \\
\hline & & 141 & re-treatment & Lead-in T12 PR48 & 89 & \\
\hline & & 68 & re-treatment & PR48 & 24 & \\
\hline \multirow[t]{4}{*}{ [40] } & G1 & 162 & naïve & T12PR24 (RGT) & 92 & ILLUMINATE \\
\hline & & 160 & naïve & T12PR48 (RGT) & 88 & study \\
\hline & & 118 & naïve & T12PR48 (non-RGT) & 64 & \\
\hline & & 100 & naïve & Discontinued treatment before wk 20 & 23 & \\
\hline
\end{tabular}


Table 3 New standard of care treatment with boceprevir for chronic hepatitis C patients

\begin{tabular}{|c|c|c|c|c|c|c|}
\hline References & G & $\begin{array}{l}\text { Number of } \\
\text { patients }\end{array}$ & $\begin{array}{l}\text { Naïve or re- } \\
\text { treatment }\end{array}$ & $\begin{array}{l}\text { Formula of therapy, and duration of treatment } \\
\text { (weeks) }\end{array}$ & $\begin{array}{l}\text { SVR rates } \\
(\%)\end{array}$ & Notes \\
\hline \multirow[t]{3}{*}{ [41] } & G1 & 363 & naive & PR48 & 38 & \multirow[t]{3}{*}{ SPRINT-2 } \\
\hline & & 368 & naive & PR4+BocPR24+PR22 & 63 & \\
\hline & & 366 & naive & PR4+BocPR44 & 66 & \\
\hline \multirow[t]{3}{*}{ [42] } & G1 & 80 & re-treatment & PR48 & 21 & \multirow{3}{*}{$\begin{array}{l}\text { HCV } \\
\text { RESPOND-2 }\end{array}$} \\
\hline & & 162 & re-treatment & PR4+BocPR24+PR22 & 59 & \\
\hline & & 161 & re-treatment & PR4+BocPR44 & 66 & \\
\hline
\end{tabular}

PR48 group received peginterferon alfa-2a and ribavirin for 48 weeks; T12PR12, T12PR24 or T12 PR48 group received telaprevir for 12 weeks and peginterferon alfa-2a and ribavirin for 12, 24 or 48 weeks, respectively; T12P12 group received telaprevir and ribavirin for 12 weeks; T24P24 group received telaprevir and peginterferon alfa-2a for 24 weeks; RGT, response-guided therapy; Boc, boceprevir.

the clinical data of first-generation protease inhibitors, telaprevir and boceprevir, these drugs showed potent inhibition of $\mathrm{HCV}$, although they occasionally led to severe adverse events $[46,47]$.

\section{Second-generation HCV NS3/4A inhibitors}

Simeprevir (TMC435) is an investigational HCV NS3/ 4A protease inhibitor administered orally once daily, and it is currently in phase III clinical development [48]. It differs from the first generation protease inhibitors in terms of its once-daily administration. Superior efficacies of simeprevir and peginterferon plus ribavirin were observed compared to those of peginterferon plus ribavirin alone in treatment-naive [49] and previously treated patients (Table 4) [50]. Although anemia and rash, respectively, were notable adverse events in boceprevir and telaprevir, those of simeprevir and peginterferon plus ribavirin did not differ from those of peginterferon plus ribavirin alone in phase II studies [48-50].

MK-5172, a novel P2-P4 quinoxaline macrocyclic peptide, maintained potency across a genetically diverse panel of genotype $1 \mathrm{a}$ and $1 \mathrm{~b}$ sequences from plasma of HCV-infected patients. This drug is to be used in combination with peginterferon plus ribavirin or with other DAAs [51]. Faldaprevir (BI 201335) is an inhibitor of

Table 4 New standard of care treatment with other drugs (second-generation DAAs) chronic hepatitis C patients

\begin{tabular}{|c|c|c|c|c|c|c|}
\hline References & G & $\begin{array}{l}\text { Number of } \\
\text { patients }\end{array}$ & $\begin{array}{l}\text { Naïve or re- } \\
\text { treatment }\end{array}$ & $\begin{array}{l}\text { Formula of therapy, and } \\
\text { duration of treatment (weeks) }\end{array}$ & $\begin{array}{l}\text { SVR } \\
\text { rates } \\
(\%)\end{array}$ & Notes \\
\hline \multirow[t]{5}{*}[48,49]{} & \multirow[t]{5}{*}{ G1 } & 78 & \multirow[t]{5}{*}{ Naïve } & $\begin{array}{l}\text { TMC435 } 12 \mathrm{~W} \text { peginterferon/ } \\
\text { ribavirin RGT }\end{array}$ & 82.1 & \multirow[t]{2}{*}{ TMC435 (simeprevir) 75 mg daily } \\
\hline & & 75 & & $\begin{array}{l}\text { TMC435 } 24 \text { W peginterferon/ } \\
\text { ribavirin RGT }\end{array}$ & 74.7 & \\
\hline & & 77 & & $\begin{array}{l}\text { TMC435 } 12 \mathrm{~W} \text { peginterferon/ } \\
\text { ribavirin RGT }\end{array}$ & 80.5 & \multirow[t]{3}{*}{ TMC435 150 mg daily } \\
\hline & & 79 & & $\begin{array}{l}\text { TMC435 } 24 \text { W peginterferon/ } \\
\text { ribavirin RGT }\end{array}$ & 86.1 & \\
\hline & & 77 & & Placebo & 64.9 & \\
\hline \multirow[t]{9}{*}[48,50]{} & \multirow[t]{9}{*}{ G1 } & 27 & \multirow[t]{3}{*}{ Relapsers } & PR PR48 & 37 & \\
\hline & & 79 & & TMC435 100 mg PR48 & 85 & \\
\hline & & 79 & & TMC435 150 mg PR48 & 85 & \\
\hline & & 23 & \multirow{3}{*}{$\begin{array}{l}\text { Partial } \\
\text { responders }\end{array}$} & PR PR48 & 9 & \\
\hline & & 68 & & TMC435 100 mg PR48 & 57 & \\
\hline & & 69 & & TMC435 150 mg PR48 & 75 & \\
\hline & & 16 & \multirow{3}{*}{$\begin{array}{l}\text { Null } \\
\text { responders }\end{array}$} & PR PR48 & 19 & \\
\hline & & 50 & & TMC435 100 mg PR48 & 46 & \\
\hline & & 51 & & TMC435 150 mg PR48 & 51 & \\
\hline \multirow[t]{4}{*}[55]{} & \multirow[t]{4}{*}{ G1 } & 12 & & 3 mg daclatasvir PR48 & 42 & \multirow{4}{*}{$\begin{array}{l}\text { Treatment-naïve or less than } 4 \text { wks of exposure to } \\
\text { ribavirin or interferon-based therapy }\end{array}$} \\
\hline & & 12 & & 10 mg daclatasvir PR48 & 83 & \\
\hline & & 12 & & 60 mg daclatasvir PR48 & 83 & \\
\hline & & 12 & & Placebo PR48 & 25 & \\
\hline
\end{tabular}


Table 5 New drugs (DAA combinations) for the treatment of hepatitis C in phase II study

\begin{tabular}{lll}
\hline Drug name/category & Drug name/category & Company \\
\hline ABT-450r/Protease inhibitor & ABT-072/Polymerase inhibitor & Abbott/Enanta \\
\hline ABT-450r/Protease inhibitor & ABT-267/NS5A inhibitor & Abbott/Enanta \\
\hline ABT-450r/Protease inhibitor & ABT-333/Polymerase inhibitor & Abbott/Enanta \\
\hline Daclatasvir (BMS-79002)/ NS5A inhibitor & Sofosbuvir (GS-7977)/ Polymerase inhibitor & Bristol-Myers Squibb/Gilead \\
\hline Daclatasvir (BMS-79002)/ NS5A inhibitor & Simeprevir (TMC435)/ Protease inhibitor & Bristol-Myers Squibb/Janssen \\
\hline Danoprevir (RG7227)/ Protease inhibitor & Setrobuvir (ANA 598)/ Polymerase inhibitor & Genentech \\
\hline Danoprevir (RG7227)/ Protease inhibitor & Mericitabine (RG7128)/ Polymerase inhibitor & Genentech \\
\hline GS-9256 & Tegobuvir (GS-9190)/ Polymerase inhibitor & Gilead \\
\hline Incivek (Telaprevir)/ Protease inhibitor & VX-222/Polymerase inhibitor & Vertex \\
\hline Mericitabine (RG7128)/ Polymerase inhibitor & Incivek (Telaprevir)/ Protease inhibitor & GenentechNVertex \\
\hline Simeprevir (TMC435)/ Protease inhibitor & Daclatasvir (BMS-79002)/ NS5A inhibitor & Janssen/Bristol-Myers Squibb \\
\hline Simeprevir (TMC435)/ Protease inhibitor & Sofosbuvir (GS-7977)/ Polymerase inhibitor & Janssen/ Gilead \\
\hline Simeprevir (TMC435)/ Protease inhibitor & TMC647055/NNI inhibitor/Ritonavir & Janssen \\
\hline Sofosbuvir (GS-7977)/ Polymerase inhibitor & GS-5885/ NS5A inhibitor & Gilead \\
\hline VX-135/Polymerase inhibitor & GSK2336805/ NS5A inhibitor & Vertex/GSK \\
\hline VX-135/Polymerase inhibitor & Simeprevir (TMC435)/ Protease inhibitor & Vertex/Janssen \\
\hline
\end{tabular}

HCV advocate: http://hcvadvocate.blogspot.ca/p/quick-reference-guide_21.html accessed on 2013/2/24.

HCV NS3/4A protease and is undergoing phase III clinical trials $[52,53]$.

\section{HCV NS5A and NS5B inhibitors}

HCV NS5A inhibitor daclatasvir (BMS-790052) with potent clinical effects has been found in the HCV replicon system [54]. Daclatasvir is a potent NS5A replication complex inhibitor and increases the antiviral potency of peginterferon and ribavirin [55] (Tables 4).

Sofosbuvir (GS-7977/PSI-7977) is a nucleotide inhibitor of HCV NS5B polymerase. Triple therapy including peginterferon plus ribavirin and sofosbuvir cures $>90 \%$ of patients treated for 12 or 24 weeks regardless of $\mathrm{HCV}$ genotype [56]. However, SVR rates of sofosbuvir plus ribavirin were $\sim 76 \%$ for interferon-naive patients and $\sim 11 \%$ for prior null responders in HCV genotype 1 patients [56,57]. Sofosbuvir plus peginterferon/ribavirin in treatment-naive patients with $\mathrm{HCV}$ genotype 1 leads to higher RVR rates and SVR rates than SOC (88-94\% vs. $21 \%$; and $56-83 \%$ vs. $43 \%$, respectively) [58]. It was also reported that sofosbuvir in combination with low- or fulldose ribavirin for 24 weeks leads to higher efficacy in difficult-to-treat HCV infected genotype 1 patients [59].

\section{HCV drugs in the future}

New drugs for the treatment of hepatitis $\mathrm{C}$ are now being investigated in phase II and phase III clinical trials (Tables 5 and 6). These include interferon-sparing regimens, which are needed for the treatment of those intolerant to, or medically ineligible for peginterferon plus

Table 6 New drugs for the treatment of hepatitis C in phase III study (combinations with peginterferon plus ribavirin, or DAA combinations)

\begin{tabular}{|c|c|c|}
\hline \multicolumn{3}{|l|}{ Combination with peginterferon plus ribavirin } \\
\hline Drug name & Category & Company \\
\hline Daclatasvir (BMS-79002) & NS5A inhibitor & Bristol-Myers Squibb \\
\hline Simeprevir (TMC435) & Protease inhibitor & Janssen \\
\hline Sofosbuvir (GS-7977) & Polymerase inhibitor & Gilead \\
\hline \multicolumn{3}{|l|}{ DAA combinations } \\
\hline Drug name/Category & Drug name/Category & Company \\
\hline ABT-450r/Protease inhibitor & ABT-267/NS5A inhibitor and/or ABT-333/Polymerase inhibitor & Abbott/Enanta \\
\hline Daclatasvir (BMS-79002)/ NS5A inhibitor & Asunaprevir (BMS-650032)/Protease inhibitor & Bristol-Myers Squibb \\
\hline Faldaprevir (BI201335)/ Protease inhibitor & GS-5885/NS5A inhibitor & Boehringer Ingelheim \\
\hline Sofosbuvir (GS-7977)/ Polymerase inhibitor & BI207127/Polymerase inhibitor & Gilead \\
\hline Sofosbuvir (GS-7977)/ Polymerase inhibitor & GS-5885/NS5A inhibitor & Gilead \\
\hline
\end{tabular}

HCV advocate: http://hcvadvocate.blogspot.ca/p/quick-reference-guide_21.html accessed on 2013/2/24. 
ribavirin therapy [60,61]. Among treatment-experienced patients with advanced fibrosis or cirrhosis, previous relapsers are likely to respond very well to telapreviror boceprevir-based treatment, although advanced liver disease had a greater influence on SVR rates in previous nonresponders $[39,42,62,63]$. Of importance is interferonsparing combinations that might potentially be used in all patients who cannot use interferon such as subjects with decompensated cirrhosis or low platelet count. Some DAAs are potent inhibitors independently of HCV genotypes [56,64-66]. The all-oral combination of daclatasvir plus sofosbuvir, with or without ribavirin, leads to higher SVR rates in treatment-naive patients chronically infected with HCV genotypes 1, 2 and 3 [67]. We may select the combination of several drugs according to personal features and/or HCV genotypes. In the near future, all-oral DAAs will treat $\mathrm{HCV}$-infected patients (Figure 1).

\section{Conclusions}

We expect that all-oral DAAs and interferon-free regimens will be applied in the treatment of HCV-infected patients and that they will have more potent efficacy and less adverse events. Further studies are now ongoing.

\section{Competing interests}

Dr. Tatsuo Kanda reports receiving lecture fees from Chugai Pharmaceutical, MSD, Ajinomoto, GlaxoSmithKlein and Mitsubishi Tanabe Pharma, and Prof. Osamu Yokosuka received grant support from Chugai Pharmaceutical, Bayer, MSD, Daiichi-Sankyo, and Mitsubishi Tanabe Pharma.

\section{Authors' contributions}

TK drafted the manuscript and all authors read through and made corrections to the manuscript. All authors read and approved the final manuscript.

\section{Author details}

'Department of Gastroenterology and Nephrology, Chiba University, Graduate School of Medicine, 1-8-1 Inohana, Chuo-ku, Chiba (260-8670), Japan. ${ }^{2}$ Yamanashi Hospitals (Central and Kita) Organization, 1-1-1 Fujimi, Kofu-shi, Yamanashi (400-8506), Japan. ${ }^{3}$ University of Tokyo, 7-3-1, Hongo, Bunkyo-ku, Tokyo (113-8655), Japan.

Received: 22 March 2013 Accepted: 8 April 2013

Published: 11 April 2013

\section{References}

1. Brownell J, Polyak SJ: Molecular pathways: hepatitis C virus, CXCL10, and the inflammatory road to liver cancer. Clin Cancer Res 2013 [Epub ahead of print].

2. El-Serag HB: Epidemiology of viral hepatitis and hepatocellular carcinoma. Gastroenterology 2012, 142:1264-1273.

3. Di Bisceglie AM, Lyra AC, Schwartz M, Reddy RK, Martin P, Gores G, Lok AS, Hussain KB, Gish R, Van Thiel DH, Younossi Z, Tong M, Hassanein T, Balart L, Fleckenstein J, Flamm S, Blei A, Befeler AS, Liver Cancer Network: Hepatitis C-related hepatocellular carcinoma in the United States: influence of ethnic status. Am J Gastroenterol 2003, 98:2060-2063.

4. Kanda T, Yokosuka O, Omata M: Hepatitis C virus and hepatocellular carcinoma. Biology 2013, 2:304-316.

5. Thomas DL, Seeff LB: Natural history of hepatitis C. Clin Liver Dis 2005 . 9:383-398.

6. Sarin SK, Kumar M: Natural history of HCV infection. Hepatol Int 2012, 6:684-694.

7. Seeff LB: Sustained virologic response: is this equivalent to cure of chronic hepatitis C? Hepatology 2013, 57:438-440.
8. Ryder SD, Irving WL, Jones DA, Neal KR, Underwood JC, Treat Hepatitis C Study Group: Progression of hepatic fibrosis in patients with hepatitis C: a prospective repeat liver biopsy study. Gut 2004, 53:451-455.

9. Barks RE, Ganne-Carrie E, Fontaine H, Paries J, Grando-Lemaire V, Beaugrand $\mathrm{M}, \mathrm{Pol} \mathrm{S}$, Trinchet JC: Effect of sustained virological response on longterm clinical outcome in 113 patients with compensated hepatitis C-related cirrhosis treated by interferon alpha and ribavirin. World J Gastroenterol 2007, 13:5648-5653.

10. Tsuda N, Yuki N, Mochizuki K, Nagaoka T, Yamashiro M, Omura M, Hikiji K, Kato M: Long-term clinical and virological outcomes of chronic hepatitis C after successful interferon therapy. J Med Virol 2004, 74:406-413.

11. Gentile I, Borgia G: Surrogate endpoints and non-inferiority trials in chronic viral hepatitis. J Hepatol 2010, 52:778.

12. Bruno S, Stroffolini T, Colombo M, Bollani S, Benvegnu L, Mazzella G, Ascione A, Santantonio T, Piccinino F, Andreone P, Mangia A, Gaeta GB, Persico M, Faqiuoli S, Almasio PL, Italian Association of the Study of the Liver Disease (AISF): Sustained virological response to interferon-alpha is associated with improved outcome in HCV-related cirrhosis: a retrospective study. Hepatology 2007, 45:579-587.

13. Ray R: Progress toward development of a hepatitis $C$ vaccine with broad shoulders. Sci Transl Med 2011, 3:94ps33.

14. Ghany MG, Strader DB, Thomas DL, Seeff LB: Diagnosis, management, and treatment of hepatitis C: an update. Hepatology 2009, 49:1335-1374.

15. European Association for the Study of the Liver: EASL clinical practice guidelines: management of hepatitis C virus infection. J Hepatol 2011, 55:245-264.

16. Omata M, Kanda T, Yu ML, Yokosuka O, Lim SG, Jafri W, Tateishi R, Hamid SS, Chuang WL, Chutaputti A, Wei L, Sollano J, Sarin SK, Kao JH, McCaughan GW: APASL consensus statements and management algorithms for hepatitis C virus infection. Hepatol Int 2012, 55:409-435.

17. Editors of the Drafting Committee for Hepatitis Management Guidelines: The Japan Society of Hepatology: Guidelines for the management of hepatitis virus infection. Hepatol Res 2013, 43:1-34.

18. Kanda T, Imazeki F, Yokosuka O: New antiviral therapies for chronic hepatitis C. Hepatol Int 2010, 4:548-561.

19. Lawitz EJ: Diagnosis and management of telaprevir-associated rash. Gastroenterol Hepatol (N.Y.) 2011, 7:469-471.

20. Tosone G, Borgia G, Gentile I, Cerini R, Conte MC, Orlando R, Piazza M: A case of pegylated interferon alpha-related diabetic ketoacidosis: can this complication be avoided? Acta Diabetol 2007, 44:167-169.

21. Honda M, Beard MR, Ping LH, Lemon SM: A phylogenetically conserved stem-loop structure at the $5^{\prime}$ border of the internal ribosome entry site of hepatitis $C$ virus is required for cap-independent viral translation. J Virol 1999, 73:1165-1174.

22. Kanda T, Steele R, Ray R, Ray RB: Small interfering RNA targeted to hepatitis $C$ virus $5^{\prime}$ nontranslated region exerts potent antiviral effect. J Virol 2007, 81:669-676.

23. Poordad F, Dieterich D: Treating hepatitis C: current standard of care and emerging direct-acting antiviral agents. J Viral Hepat 2012, 19:449-464.

24. Fried MW, Shiffman ML, Reddy KR, Smith C, Marinos G, Goncales FL Jr, Haussinger D, Diago M, Carosi G, Dhumeaux D, Caraxi A, Lin A, Hoffman J, Yu J: Peginterferon alfa-2a plus ribavirin for chronic hepatitis $C$ virus infection. N Engl J Med 2002, 347:975-982.

25. Muir AJ, Bornstein JD, Killenberg PG, Atlantic Coast Hepatitis Treatment Group: Peginterferon alfa- $2 \mathrm{~b}$ and ribavirin for the treatment of chronic hepatitis $\mathrm{C}$ in blacks and non-Hispanic whites. N Engl J Med 2004, 350:2265-2271.

26. Shiffman ML, Suter F, Bacon BR, Nelson D, Harley H, Sola R, Shafran SD, Barange K, Lin A, Soman A, Zeuzem S, ACCELERATE Investigators: Peginterferon alfa-2a and ribavirin for 16 or 24 weeks in HCV genotype 2 or 3. N Engl J Med 2007, 357:124-134.

27. Rodriguez-Torres M, Jeffers $\amalg$, Sheikh MY, Rossaro L, Ankoma-Sey V, Hamzeh FM, Martin P, Latino Study Group: Peginterferon alfa-2a and ribavirin in Latino and non-Latino whites with hepatitis C. N Engl J Med 2009, 360:257-267.

28. Borgia G, Gentile I, Fortunato G, Borrelli F, Borelli S, de Caterina M, Di Taranto MD, Simone M, Borgia F, Viola C, Reynaud L, Cerini R, Sacchetti L: Homocysteine levels and sustained virological response to pegylatedinterferon alpha2b plus ribavirin therapy for chronic hepatitis $\mathrm{C}$ : a prospective study. Liver Int 2009, 29:248-252.

29. Ge D, Fellay J, Thompson AJ, Simon JS, Shianna KV, Urban TJ, Heinzen EL, Qiu P, Bertelsen AH, Muir AJ, Sulkowski M, McHutchison JG, Goldstein DB: 
Genetic variation in IL28B predicts hepatitis C treatment-induced viral clearance. Nature 2009, 461:399-401.

30. Tanaka Y, Nishida N, Sugiyama M, Kuroki M, Matsuura K, Sakamoto $N_{\text {, }}$ Nakagawa M, Korenaga M, Hino K, Ito Y, Mita E, Tanaka E, Mochida S, Murawaki Y, Honda M, Sakai A, Hiasa Y, Nishiguchi S, Koike A, Sakaida I, Imamura M, Ito K, Yano K, Masaki N, Sugauchi F, Izumi N, Tokunaga K, Mizokami M: Genome-wide association of IL28B with response to pegylated interferon-alpha and ribavirin therapy for chronic hepatitis $C$. Nat Genet 2009, 41:1105-1109.

31. Suppiah V, Moldovan M, Ahlenstiel G, Berg T, Weltman M, Abate ML, Bassendine M, Spengler U, Dore GJ, Powell E, Riordan S, Sheridan D, Smedile A, Fragomeli V, Muller T, Bahlo M, Stewart GJ, Booth DR, George J: $\mathrm{IL} 28 \mathrm{~B}$ is associated with response to chronic hepatitis $C$ interferon-alpha and ribavirin therapy. Nat Genet 2009, 41:1100-1104.

32. Nakamoto S, Kanda T, Imazeki F, Wu S, Arai M, Fujiwara K, Yokosuka O: Simple assay based on restriction fragment length polymorphism associated with IL28B in chronic hepatitis C patients. Scand J Gastroenterol 2011, 46:955-961.

33. Miyamura T, Kanda T, Nakamoto S, Wu S, Fujiwara K, Imazeki F, Yokosuka O Hepatic STAT1-nuclear translocation and interleukin 28B polymorphisms predict treatment outcomes in hepatitis $C$ virus genotype 1-infected patients. Plos One 2011, 6:e28617.

34. Miyamura T, Kanda T, Nakamoto S, Wu S, Jiang X, Arai M, Fujiwara K, Imazeki F, Yokosuka O: Roles of ITPA and IL28B genotypes in chronic hepatitis C patients treated with peginterferon plus ribavirin. Viruses 2012, 4:1264-1278.

35. McHutchison JG, Everson GT, Gordon SC, Jacobson IM, Sulkowski M, Kauffman R, McNair L, Alam J, Muir AJ, PROVE1 Study Team: Telaprevir with peginterferon and ribavirin for chronic HCV genotype 1 infection. N Engl J Med 2009, 360:1827-1838.

36. Hezode C, Forestier N, Dusheiko G, Ferenci P, Pol S, Goeser T, Bronowicki JP, Bourliere M, Gharakhanian S, Bengtsson L, McNair L, George S, Kieffer T, Kwong A, Kauffman RS, Alam J, Pawlotsky JM, Zeuzem S, PROVE2 Study Team: Telaprevir and peginterferon with or without ribavirin for chronic HCV infection. N Engl J Med 2009, 360:1839-1850.

37. McHutchison JG, Manns MP, Muir AJ, Terrault NA, Jacobson IM, Afdhal NH, Heathcote EJ, Zeuzem S, Reesink HW, Garg J, Bsharat M, George S, Kauffman RS, Adda N, Di Bisceglie AM, PROVE3 Study Team: Telaprevir for previously treated chronic HCV infection. N Engl J Med 2010, 362:1292-1303.

38. Jacobson IM, McHutchison JG, Dusheiko G, Di Bisceglie AM, Reddy KR, Bzowej NH, Marcellin P, Muir AJ, Flisiak R, George J, Rizzetto M, Shouval D, Sola R, Terg RA, Yoshida EM, Adda N, Bengtsson L, Sankoh AJ, Kieffer TL, George S, Kauffman RS, Zeuzem S, ADVANCE Study Team: Telaprevir for previously untreated chronic HCV infection. N Engl J Med 2011, 364:2405-2416.

39. Zeuzem S, Andreone P, Pol S, Lawitz E, Diago M, Roberts S, Focaccia R, Younossi Z, Foster GR, Horban A, Ferenci P, Nevens F, Mullhaupt B, Pockros P, Terg R, Shouval D, van Hoek B, Weiland O, Van Heeswijk R, De Meyer S, Luo D, Boogaerts G, Polo R, Picchio G, Beumont M, REALIZE Study Team: Telaprevir for retreatment of HCV infection. N Engl J Med 2011, 364:2417-2428.

40. Sherman KE, Flamm SL, Afdhal NH, Nelson DR, Sulkowski MS, Everson GT, Fried MW, Adler M, Reesink HW, Martin M, Sankoh AJ, Adda N, Kauffman RS, George S, Wright Cl, Poordad F, ILLUMINATE Study Team: Response-guided teraprevir combination treatment for hepatitis $C$ virus infection. N Engl J Med 2011, 365:1014-1024.

41. Poordad F, McCone J Jr, Bacon BR, Bruno S, Manns MP, Sulkowski MS, Jacobson IM, Reddy KR, Goodman ZD, Boparai N, DiNubile MJ, Sniukiene V, Brass CA, Albrecht JK, Bronowicki JP, SPRINT-2 Investigators: Boceprevir for untreated chronic HCV genotype 1 infection. N Engl J Med 2011, 364:1195-1206.

42. Bacon BR, Gordon SC, Lawitz E, Marcellin P, Vierling JM, Zeuzem S, Poordad F, Goodman ZD, Sings HL, Boparai N, Burroughs M, Brass CA, Albrecht JK Esteban R, HCV RESPOND-2 Investigators: Boceprevir for previously treated chronic HCV genotype 1 infection. N Engl J Med 2011, 364:1207-1217.

43. Lin C, Kwong AD, Perni RB: Discovery and development of VX-950, a novel, covalent, and reversible inhibitor of hepatitis $C$ virus NS3.4A serine protease. Infect Disord Drug Targets 2006, 6:3-16.

44. Gentile I, Viola C, Borgia F, Castaldo G, Borgia G: Telaprevir: a promising protease inhibitor for the treatment of hepatitis $C$ virus infection. Cur Med Chem 2009, 16:1115-1121.

45. Bogen SL, Pan W, Ruan S, Nair LG, Arasappan A, Bennett F, Chen KX, Jao E, Venkatraman S, Liu R, Cheng KC, Guo Z, Tong X, Saksena AK, Girijavallabhan
V, Njoroge FG: Toward the back-up of boceprevir (SCH 503034): discovery of new extended P4-capped ketoamide inhibitors of hepatitis $C$ virus NS3 serine protease with improved potency and pharmacokinetic profiles. J Med Chem 2009, 52:3679-3688.

46. Chopra A, Klein PL, Drinnan T, Lee SS: How to optimize HCV therapy in genotype 1 patients: management of side-effects. Liver Int 2013, 33(Suppl 1):30-34.

47. Kumada H, Toyoda J, Okanoue T, Chayama K, Tsubouchi H, Hayashi N: Telaprevir with peginterferon and ribavirin for treatment-naive patients chronically infected with HCV of genotype 1 in Japan. J Hepatol 2012, 56:78-84.

48. Tanwar S, Trembling PM, Dusheiko GM: TMC435 for the treatment of chronic hepatitis C. Expert Opin Investig Drugs 2012, 21:1193-1209.

49. Aerssens J, Fanning F, Scholliers A, Lenz O, Peeters M, De Smedt G, Fried M: Impact of IL28B genotype and pretreatment serum IP-10 in treatmentnaive genotype-1 HCV patients treated with TMC435 in combination with peginterferon a-2A and ribavirin in PILLAR Study. J Hepatol 2011, 54(Suppl 1):S5-S6.

50. Zeuzem S, Berg T, Gane E, Ferenci P, Foster GR, Fried MW, Hezode C, Hirschfield GM, Jacobson I, Nikitin I, Pockros P, Poordad F, Lenz O, Peeters M, Sekar V, De Smedt G, Beumont-Mauviel M: TMC435 in HCV genotype 1 patients who have failed previous pegylated interferon/ribavirin treatment: final SVR24 results of the ASPIRE TRIAL. J Hepatol 2012, 56(Suppl 2):S1-S2.

51. Summa V, Ludmerer SW, McCauley JA, Fandozzi C, Burlein C, Claudio G, Coleman PJ, Dimuzio JM, Ferrara M, Di Filippo M, Gates AT, Graham DJ, Harper S, Hazuda DJ, McHale C, Monteaqudo E, Pucci V, Rowley M, Rudd MT, Soriano A, Stahlhut MW, Vacca JP, Olsen DB, Liverton NJ, Carroll SS: MK-5172, a selective inhibitor of hepatitis C virus NS3/4a protease with broad activity across genotypes and resistant variants. Antimicrob Agents Chemother 2012, 56:4161-4167.

52. Zeuzem S, Asselah T, Angus P, Zarski JP, Larrey D, Mullhaupt B, Gane E, Schuchmann M, Lohse A, Pol S, Bronowicki JP, Roberts S, Arasteh K, Zoulim F, Heim M, Stern JO, Kukolj G, Nehmiz G, Haefner C, Boecher WO: Efficacy of the protease inhibitor BI 201335, polymerase inhibitor BI 207127, and ribavirin in patients with chronic HCV infection. Gastroenterology 2011, 141:2047-2055

53. Cooper C: Hepatitis $C$ treatment highlights from the 2011 American Association for the Study of Liver Disease Meeting. Clin Infect Dis 2012, 55:418-425.

54. Gao M, Nettles RE, Belema M, Snyder LB, Nguyen VN, Fridell RA, Serrano-Wu MH, Langley DR, Sun JH, O'Boyle DR 2nd, Lemm JA, Wang C, Knipe JO, Chien C, Colonno RJ, Grasela DM, Meanwell NA, Hamann LG: Chemical genetics strategy identifies an HCV NS5A inhibitor with a potent clinical effect. Nature 2010, 465:96-100.

55. Pol S, Ghalib RH, Rustgi VH, Martorell C, Everson GT, Tatum HA, Hezode C, Lim JK, Bronowicki JP, Abrams GA, Brau N, Morris DW, Thuluvath PJ, Reindollar RW, Yin PD, Diva U, Hindes R, McPhee F, Hemandez D, WindRotolo M, Hughes EA, Schnittman S: Daclatasvir for previously untreated chronic hepatitis $C$ genotype-1 infection: a randomised, parallel-group, double-blind, placebo-controlled, dose-finding, phase 2a trial. Lancet Infect Dis 2012, 12:671-677.

56. Barreiro P, Vispo E, Poveda E, Fernandez-Montero JV, Soriano V: Hepatitis C therapy: Highlights from the 2012 annual meeting of the European association for the study of the liver. Clin Infect Dis 2013, 56:560-566.

57. Gane EJ, Stedman CA, Hyland RH, Sorensen RD, Symonds WT, Hindes R, Berrey MM: Once daily sofosbuvir (GS-7977) plus ribavirin in patients with HCV genotypes 1, 2, and 3: the ELECTRON trial. Hepatology 2013, 56(suppl):306A

58. Rodriguez-Torres M, Lawitz E, Kowdley KV, Nelson DR, Dejesus E, McHutchison JG, Cornpropst MT, Mader M, Albanis E, Jiang D, Hebner CM, Symonds WT, Berry MM, Lalezari J: Sofosbuvir (GS-7977) plus peginterferon/ribavirin in treatment-naive patients with HCV genotype 1: A randomized, 28-day, dose-ranging trial. J Hepatol 2012 [Epub ahead of print].

59. Osinusi A, Heytens L, Lee $Y$, Bon D, Shivakumar B, Nelson A, Meissner EG, Kohli A, Barrett L, Proschan M, Silk R, Kwan R, Herrmann E, Sneller M, Teferi G, Talwani R, Symonds WT, Polis MA, Mausur H, McHuchison JG, Fauci AS, Kottilil S: High efficacy of GS-7977 in combination with low or full dose ribavirin for 24 weeks in difficult to treat HCV infected genotype 1 patients: interim analysis from SPARE trial. Boston, Massachusetts: Program and abstracts of 63rd Annual Meeting of the American Association for the Study of Liver Diseases; 2012. Abstract LB-4.

60. Karino Y, Toyoda J, Ikeda K, Suzuki F, Chayama K, Kawakami Y, Ishikawa H, Watanabe H, Hemandez D, Yu F, McPhee F, Kumada H: Characterization of 
virologic escape in hepatitis $C$ virus genotype $1 \mathrm{~b}$ patients treated with the direct-acting antivirals daclatasvir and asunaprevir. J Hepatol 2012 [Epub ahead of print].

61. Suzuki Y, Ikeda K, Suzuki F, Toyoda J, Karino Y, Chayama K, Kawakami Y, Ishikawa H, Watanabe H, Hu W, Eley T, McPhee F, Hughes E, Kumada H: Dual oral therapy with daclatasvir and asunaprevir for patients with HCV genotype $1 \mathrm{~b}$ infection and limited treatment options. J Hepatol 2012 [Epub ahead of print].

62. Muir AJ, Poordad FF, McHutchison JG, Shiffman ML, Berg T, Ferenci P, Heathcote EJ, Pawlotsky JM, Zeuzem S, Reesink HW, Dusheiko G, Martin EC, George S, Kauffman RS, Adda N: Retreatment with telaprevir combination therapy in hepatitis C patients with well-characterized prior treatment response. Hepatology 2011, 54:1538-1546.

63. Jacobson IM, Pawlotsky JM, Afdhal NH, Dusheiko GM, Forns X, Jensen DM, Poordad F, Schulz J: A practical guide for the use of boceprevir and telaprevir for the treatment of hepatitis C. J Viral Hepat 2012, 19(Suppl 2):1-26.

64. Lok AS, Gardiner DF, Lawitz E, Martorell C, Everson GT, Ghalib R, Reindollar R, Rustgi V, McPhee F, Wind-Rotolo M, Persson A, Zhu K, Dimitrova DI, Eley T, Guo T, Grasela DM, Pasquinelli C: Preliminary study of two antiviral agents for hepatitis C genotype 1. N Engl J Med 2012, 366:216-224.

65. Gane EJ, Stedman CA, Hyland RH, Ding X, Svarovskaia E, Symonds WT, Hindes RG, Berrey MM: Nucleotide polymerase inhibitor sofosbuvir plus ribavirin for hepatitis C. N Engl J Med 2013, 368:34-44.

66. Herbst DA Jr, Reddy KR: Sofosbuvir, a nucleotide polymerase inhibitor, for the treatment of chronic hepatitis C virus infection. Expert Opin Investig Drugs 2013 [Epub ahead of print]

67. Sulkowski MS, Gardiner DF, Rodriguez-Torres M, Reddy KR, Hassanein T, Jacobson IM, Lawitz E, Lok AS, Hinestrosa F, Thuluvath PJ, Schwartz H, Nelson DR, Eley T, Wind-Rotolo M, Huang SP, Gao M, McPhee F, Sherman D, Hindes R, Symonds WT, Pasquinelli C, Grasela DM: High rate of sustained virologic response with the all-oral combination of daclatasvir (NS5A inhibitor) plus sofosbuvir (nucleotide NS5B inhibitor), with or without ribavirin, in treatmentnaive patients chronically infected with HCV genotype 1, 2, or 3. Boston, Massachusetts: Program and abstracts of 63rd Annual Meeting of the American Association for the Study of Liver Diseases; 2012. Abstract LB-2.

doi:10.1186/2001-1326-2-9

Cite this article as: Kanda et al:: Treatment of hepatitis $C$ virus infection in the future. Clinical and Translational Medicine 2013 2:9.

\section{Submit your manuscript to a SpringerOpen ${ }^{\circ}$ journal and benefit from:}

- Convenient online submission

- Rigorous peer review

- Immediate publication on acceptance

- Open access: articles freely available online

- High visibility within the field

- Retaining the copyright to your article

Submit your next manuscript at $\gg$ springeropen.com 